\title{
Performance of Combined A/O Moving-Bed Biofilm Reactors for Biological Nutrients Removal from Domestic Wastewater under Different Gas/Water Ratios
}

\author{
Ali H. Al-Aboodi $\mathbb{D}^{1},{ }^{1}$ Ayman Alak Hassan, ${ }^{1}$ and Musa Habib Jassim Al-Shammari ${ }^{2}$ \\ ${ }^{1}$ Civil Engineering Department, Engineering College, University of Basrah, Basrah, Iraq \\ ${ }^{2}$ Civil Engineering Department, Engineering College, University of Karbala, Karbala, Iraq \\ Correspondence should be addressed to Ali H. Al-Aboodi; alialaboodi90@gmail.com
}

Received 22 February 2020; Revised 21 March 2020; Accepted 31 March 2020; Published 19 April 2020

Academic Editor: Justo Lobato

Copyright (c) 2020 Ali H. Al-Aboodi et al. This is an open access article distributed under the Creative Commons Attribution License, which permits unrestricted use, distribution, and reproduction in any medium, provided the original work is properly cited.

\begin{abstract}
In this experimental research, the continuous-upflow lab-scale combined A/O Moving-Bed Biofilm Reactors (MBBRs), with 50\% $\mathrm{A} / \mathrm{O}$ volume ratio and $100 \%$ internal $\mathrm{NO}_{3}{ }^{-}$recycling ratio, were constructed to treat $60 \mathrm{~L} /$ day of domestic wastewater in Basra Province (Southern Iraq) under full nitrification-denitrification processes. The A/O treatment system consists of Plexiglas square anoxic reactor with effective volume (15 litters), Plexiglas square aerobic reactor with effective volume (30 litters), and 250-litter Plexiglas square primary and final settling tanks. Cylindrical K1 plastic Kaldnes carriers with density of $0.93 \mathrm{~g} / \mathrm{cm}^{3}$ were added to both reactors with $60 \%$ filling ratio to achieve the process of biofilm attaching. The $\mathrm{A} / \mathrm{O}$ treatment system was operated under the batch mode for four weeks for development of biofilm; then the system was operated in continuous-upflow mode with total hydraulic retention time (HRT) equal to 18 hours and five different gas: water ratios $(5: 1,7: 1,10: 1,15: 1$, and $20: 1)$ in order to investigate the effect of gas: water ratio on the total performance of A/O system. The study results illustrated that gas: water ratio has no effect on the removing of $\mathrm{NH}_{4}{ }^{+}-\mathrm{N}$ and COD, while it significantly affects the removing of TP and TN. The optimum value of gas : water ratio is $7: 1$, with the average value of removal efficiency $(\mathrm{R} \%)$ of $\mathrm{TP}, \mathrm{TN}, \mathrm{NH}_{4}{ }^{+}-\mathrm{N}$, and COD being $84.49 \%, 78.67 \%$, $97.27 \%$, and $95.56 \%$, respectively. Under this value of gas : water ratio, the average values of dissolved oxygen (DO) in both aerobic MBBR and anoxic MBBR are $3.96 \mathrm{mg} / \mathrm{L}$ and $0.181 \mathrm{mg} / \mathrm{L}$, respectively.
\end{abstract}

\section{Introduction}

For more than one century, the traditional techniques were used in order to treat the municipal wastewater, such as the technology of conventional activated sludge. These techniques need to expand numerous times in order to produce higher quality effluent due to the increase of hydraulic and organic loads, with stringent limitation of discharge for various pollutants. The conventional activated sludge process was even modified numerous times in order to meet all challenges, but it still has some shortcomings such as sludge rising, sludge treatment, and large footprint. Therefore, it is necessary to present an alternative and successful technology with minimum reactors volume in order to treat different kinds of effluents. The process of Moving-Bed Biofilm
(MBB) was presented to overcome the drawbacks identified in the process of conventional activated sludge [1-4].

Today, the technology of MBB became the most famous and alternative process for wastewater treatment under different conditions, especially for nitrogen and phosphorus removal from different kinds of wastewater such as landfill leachate [5], domestic wastewater [2, 3, 6-13], dairy wastewater $[14,15]$, cheese factory wastewater [16], paper industry wastewater [17], and fish farming wastewater [18]. Firstly, this technology was developed in Norway in 1990 and then introduced in United States in 1995; in 2009 more than 600 municipal and industrial wastewater treatment plants used the technology of MBB in 50 different countries all over the world $[4,19]$. MBB technology is based on the principle of biofilm that offers the advantages of both 
attached and suspended biomass systems, in order to be more reliable than activated sludge process for organic carbon and nutrients removal without any disadvantages, by adding small polyethylene media elements with density less than the density of water $\left(<1 \mathrm{~g} / \mathrm{cm}^{3}\right)$ and with a large surface area into the reactors for biofilm attachment. This way, the media elements will allow a high concentration of biomass in the reactors compared to the process of suspended growth, and the reactor volume is totally mixed without any unused or dead part in the reactor $[3,14,20-24]$.

After 25 years of continuous operation of MBB process, the researchers concluded that the main benefits of this technology include the following [24-26]:

(1) Small head loss

(2) No sludge recycling

(3) Small size units with compact form

(4) Reduced sludge production without any problems in sludge bulking

(5) Increased treatment capacity

(6) No need for filter channeling and periodic backwash

Sixty to seventy percent from the total nitrogen (TN) in domestic wastewater is ammonium $\left(\mathrm{NH}_{4}{ }^{+} \mathrm{N}\right)$ which derived from rapidly breaks down of urea [27, 28]. In domestic wastewater, the total phosphorus (TP) is present as it is an essential nutrient and part of the energy cycle of a cell. It is used in detergents, cleaning agents, and fertilizers and is present in human and animal waste. The high levels of TN and TP in wastewater cause many problems, such as toxicity, eutrophication, and oxygen consumption. The controlling of the TN and TP concentrations in wastewater discharge into the environment is becoming more stringent, for regulations of the eutrophication rate, and this led to considering the TN and TP as a major concern in the design and operation of wastewater treatment facilities $[2,3]$.

TN removal from the wastewater can be achieved by a combination of nitrification process (under the condition of aeration) and denitrification process (under anoxic or anaerobic conditions) $[2,25]$. The most important problem in biological nutrients removal from wastewater is the removal of $\mathrm{NH}_{4}{ }^{+}-\mathrm{N}$ [29]. In aerobic reactor and under the process of full nitrification, the $\mathrm{NH}_{3}{ }^{+}-\mathrm{N}$ is firstly converted to nitrite $\left(\mathrm{NO}_{2}^{-}\right)$by Nitrosomonas bacteria, and then the Nitrobacter microorganisms oxidize the $\mathrm{NO}_{2}{ }^{-}$to nitrate $\left(\mathrm{NO}_{3}{ }^{-}\right)[7,25,30]$. The $\mathrm{NH}_{3}{ }^{+}-\mathrm{N}$ oxidation is strongly dependent on the concentration of dissolved oxygen (DO); at least $2 \mathrm{mg} / \mathrm{L}$ of DO is normally used in the process of full nitrification, while DO concentration becomes in the range of $0.5-1.5 \mathrm{mg} / \mathrm{L}$ under the process of partial nitrification $\left(\mathrm{NH}_{3}{ }^{+}-\mathrm{N}\right.$ oxidized to $\mathrm{NO}_{2}{ }^{-}$only) [30-35]. On the other hand, the denitrification process can be achieved in anoxic and/or in anaerobic reactor $(\mathrm{DO}<0.5 \mathrm{mg} / \mathrm{L})$ by using $\mathrm{NO}_{3}{ }^{-}$and $\mathrm{NO}_{2}{ }^{-}$as electron acceptors instead of oxygen for organic matter oxidation; $\mathrm{NO}_{3}{ }^{-}$is converted to $\mathrm{NO}_{2}{ }^{-}$then to nitrous oxide $\left(\mathrm{N}_{2} \mathrm{O}\right), \mathrm{N}_{2} \mathrm{O}$ is converted to nitric oxide (NO), and finally the $\mathrm{NO}$ is converted to nitrogen gas $\left(\mathrm{N}_{2}\right)[25,29,36,37]$.
In this research, the effects of gas: water ratio on the removal of chemical oxygen demand (COD), $\mathrm{NH}_{4}{ }^{+}-\mathrm{N}, \mathrm{TN}$, and TP from domestic wastewater in Basrah Province (Southern Iraq) were investigated using the technology of upflow combined A/O Moving-Bed Biofilm Reactors with $50 \% \mathrm{~A} / \mathrm{O}$ volume ratio, $100 \%$ internal nitrate recycle ratio, and $60 \%$ carriers filling ratio in both reactors. In order to evaluate the optimum value of gas: water ratio, the $\mathrm{A} / \mathrm{O}$ system was operated under five different ratios $(5: 1,7: 1,10$ : $1,15: 1$, and $20: 1)$.

\section{Materials and Methods}

2.1. Experimental Setup. The designed experiments were conducted using continuous-upflow lab-scale combined A/ $\mathrm{O}$ MBBRs in series form to treat $60 \mathrm{~L} /$ day from domestic wastewater in Basra Province (Southern Iraq). The A/O treatment system consists of Plexiglas square primary settling tank $(0.75 \mathrm{~m} \times 0.75 \mathrm{~m} \times 0.5 \mathrm{~m})$, Plexiglas square anoxic reactor with total effective volume of 15 litters $(0.25 \mathrm{~m} \times 0.25 \mathrm{~m} \times 0.3 \mathrm{~m})$, and Plexiglas square aerobic reactor with total effective volume of 30 litters $(0.35 \mathrm{~m} \times 0.35 \mathrm{~m} \times 0.3 \mathrm{~m})$ followed by a Plexiglas square final clarifier $(0.75 \mathrm{~m} \times 0.75 \mathrm{~m} \times 0.5 \mathrm{~m})$. The anoxic MBBR was built in order to achieve the denitrification process, while the aerobic MBBR was constructed to provide the full nitrification process. In order to collect samples, the sampling ports were provided in each reactor. In this research, the cylinder plastic Kaldnes K1 carriers $(25 \mathrm{~mm} \times 10 \mathrm{~mm})$ with $500 \mathrm{~m}^{2} / \mathrm{m}^{3}$ surface growth area and $0.93 \mathrm{~g} / \mathrm{cm}^{3}$ density were used for attached biofilm growth in both anoxic and aerobic MBBRs with filling ratio equal to $60 \%$. The biofilm carrier elements were retained inside the MBBRs using a small size sieve with two-millimeter opening diameter. Figure 1 shows the sketch of the lab-scale A/O MBBRs.

The biofilm carriers were kept in continuous movement inside the aerobic reactor by the action of aeration system, which consists of two fine bubble diffusers at $0.05 \mathrm{~m}$ from the bottom of aerobic MBBR, air compressor with capacity equal to $150 \mathrm{~L} / \mathrm{min}$, rotameter, and regulated valve. Anoxic MBBR was stirred by the propeller mixer in reactor center with fixed propeller speed of $50 \mathrm{rpm}$. The temperature inside the reactors was controlled in the range of $25^{\circ} \mathrm{C} \pm 1^{\circ} \mathrm{C}$ using aquarium heaters.

2.2. Procedure of Operation. Research experiments were done from May 2018 to the end of October 2018 (approximately 6 months). The reactors of the A/O system are inoculated with activated sludge from the municipal wastewater treatment plant of HAMDAN (Basra Province, Southern Iraq). First, the seed sludge was screened with small size sieve to remove any inorganic materials and then aerated for 3 days at the temperature of the room. Finally, the aerated sludge was mixed with the domestic wastewater by $67 \%$ ratio, and $34 \%$ of each $\mathrm{A} / \mathrm{O}$ reactor was filled. The startup phase began by operating the system in batch mode (2hour fill, 18-hour aeration with gas : water ratio equal to $10 / 1$ in aerobic MBBR and mixing in anoxic MBBR, 2-hour 


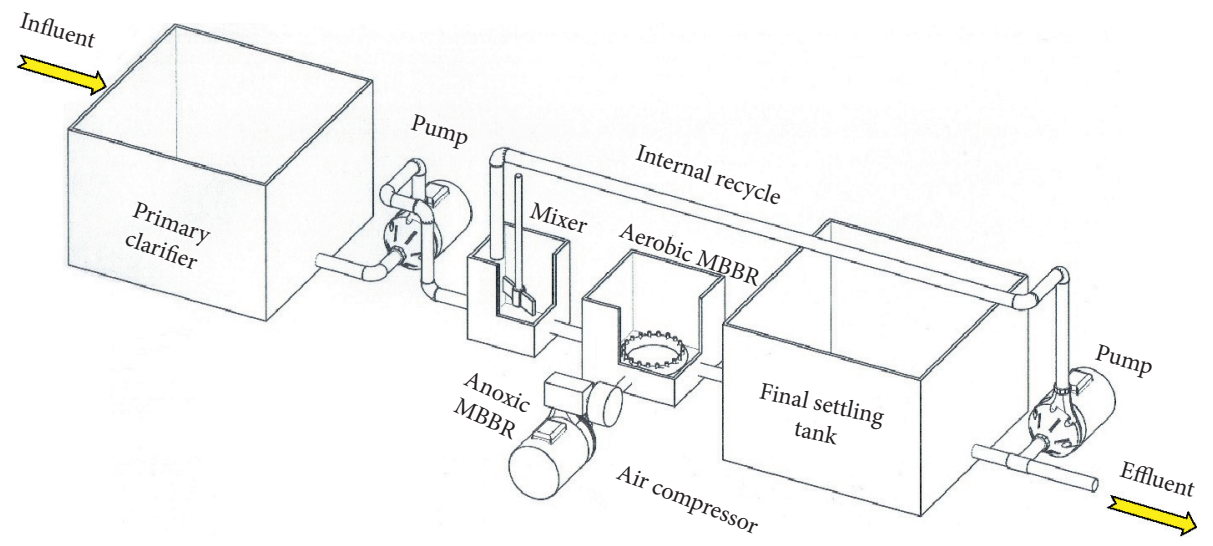

Figure 1: Sketch of the lab-scale A/O MBBRs.

settling time, and 2 hours for $100 \%$ discharge period). The Kaldnes $\mathrm{K} 1$ media elements were acclimated in the batch mode for 4 weeks for development of biofilm.

After start-up period was finished the biofilm appeared on carrier elements, and the total concentrations of the mixed liquor suspended solids (MLSS) reached $2364 \mathrm{mg} / \mathrm{L}$ and $3640 \mathrm{mg} / \mathrm{L}$ in both MBBRs, respectively. At the start of the 5th week, the A/O system was operated in continuous mode with total HRT of 18 hours (anoxic HRT of 6 hours and aerobic HRT of 12 hours), $100 \%$ internal nitrate recycle ratio, five different gases and water ratios of $5: 1,7: 1,10: 1,15: 1$, and $20: 1$. During this operation mode, the average concentrations of $\mathrm{pH}$ in both anoxic MBBR and aerobic MBBR equal 7.64 and 7.47, respectively, while the average concentrations of total MLSS were $2151 \mathrm{mg} / \mathrm{L}$ and $3219 \mathrm{mg} / \mathrm{L}$, respectively.

All samples of ammonium, total phosphorus, total nitrogen, and chemical oxygen demand were collected from the $\mathrm{A} / \mathrm{O}$ system 2 times a week and analyzed in accordance with the standard methods mentioned in APHA (2005) [38]. $\mathrm{pH}, \mathrm{DO}$, and temperature were measured in both reactors immediately before sampling. The concentration of the attached biofilm in the Kaldnes K1 carrier elements was obtained according to the method described by $[11,12,17,39]$.

\section{Results and Discussion}

The continuous-upflow lab-scale combined A/O MBBRs with $50 \% \mathrm{~A} / \mathrm{O}$ volume ratio were built to treat $60 \mathrm{~L} /$ day from the domestic wastewater in Basra Province (Southern Iraq) under full nitrification-denitrification processes (DO concentration in aerobic $\mathrm{MBBR} \geq 2 \mathrm{mg} / \mathrm{L}$ ) for simultaneous removal of COD, TN, and TP. The treating system was operated without sludge recycle and with total HRT of 18 hours, internal $\mathrm{NO}_{3}{ }^{-}$recycle ratio of $100 \%$, and 5 different gas: water ratios $(5: 1,7: 1,10: 1,15: 1$, and $20: 1)$ in order to evaluate the optimum value of gas: water ratio giving the best nutrients removal. The experimental operation data of A/O system were presented in Tables 1 and 2 and shown in Figures 2-11.
TABLE 1: Characteristics of domestic wastewater during continuous operation mode.

\begin{tabular}{lccc}
\hline \multirow{2}{*}{ Pollutants } & \multicolumn{3}{c}{ Concentrations $(\mathrm{mg} / \mathrm{L})$} \\
& Range & Average & Standard deviation \\
\hline COD & $183.8-397.2$ & 311.27 & 69.14 \\
$\mathrm{NH}_{4}{ }^{+}-\mathrm{N}$ & $25.3-53.9$ & 39.72 & 9.22 \\
$\mathrm{TN}$ & $26.76-58.5$ & 45.27 & 10.01 \\
$\mathrm{TP}$ & $2.02-6.11$ & 3.59 & 1.07 \\
\hline
\end{tabular}

Nitrification process is highly dependent on the concentration of DO in terms of its effect on the growth rates of Nitrosomonas and Nitrobacter microorganisms. According to Wiesmann, the influence of the DO concentration on the Nitrobacter bacteria (about $1.1 \mathrm{mg} / \mathrm{L}$ ) was greater than that on the Nitrosomonas bacteria (about $0.3 \mathrm{mg} / \mathrm{L}$ ) [40]. Park and Noguera observed changes in the specific population growth of Nitrobacter bacteria under low DO concentration [41]. Both the concentration of DO in the aerobic reactor and the internal $\mathrm{NO}_{3}{ }^{-}$recycling ratio have great effects on the DO concentration in the anoxic reactor and consequently on the denitrification rate. The reactions of denitrification can be inhibited by the increase of DO in anoxic MBBR because oxygen functions as the electron acceptor instead of $\mathrm{NO}_{3}{ }^{-}$, and the enzymes involved in denitrification will be repressed by the action of aerobic conditions $[2,3,42]$. As the rate of nitrification increases, the denitrification rate increases and more organic carbon will be removed provided that the DO concentration in the anoxic reactor remains within the permissible limits $(\mathrm{DO}<0.5 \mathrm{mg} /$ L) $[2,3,43]$. Under anoxic condition part of the $\mathrm{NH}_{4}{ }^{+}-\mathrm{N}$ and COD was consumed by denitrifying phosphate-accumulating organisms in order to treat some of the TP using only $\mathrm{NO}_{3}{ }^{-}$as electronic acceptor $[2,3,44,45]$; also some of $\mathrm{NH}_{4}{ }^{+}-\mathrm{N}$ is converted directly to dinitrogen gas by using only $\mathrm{NO}_{2}{ }^{-}$as electronic acceptor [46, 47]. Under aerobic condition, the COD is consumed by a contest between heterotrophic microorganisms and phosphate-accumulating bacteria, while the DO is consumed by Nitrosomonas bacteria, Nitrobacter bacteria, phosphate-accumulating bacteria, and heterotrophic microorganisms [2, 3, 25]. 


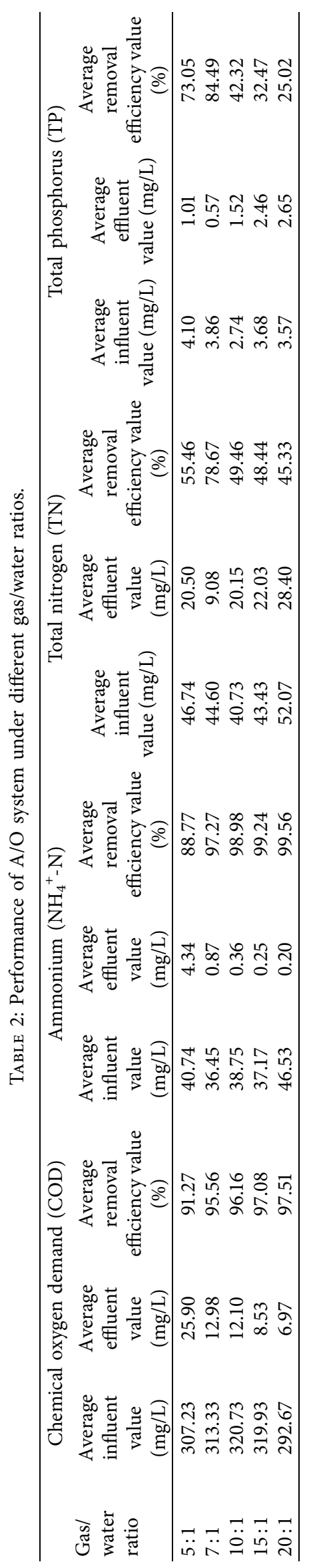




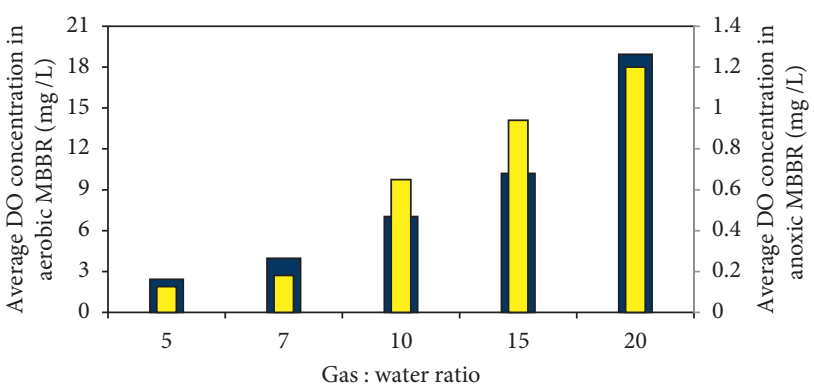

- Average DO concentration in aerobic MBBR

口 Average DO concentration in anoxic MBBR

FIgURE 2: The average concentration of DO in A/O MBBRs system under different gas: water ratios.

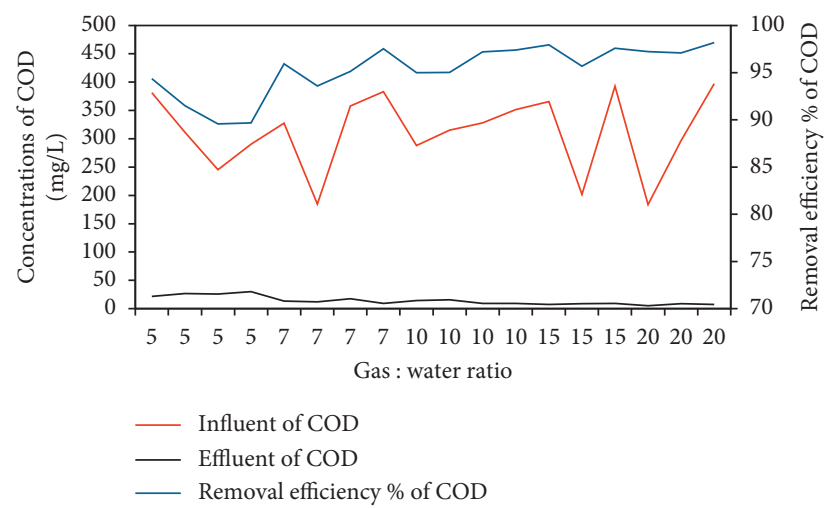

Figure 3: Performance of A/O MBBRs system for COD removal under different gas : water ratios.

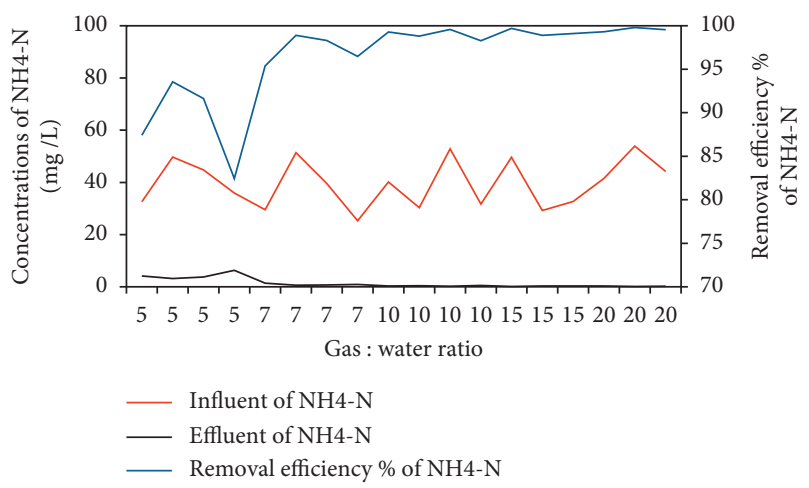

Figure 4: Performance of A/O MBBRs system for $\mathrm{NH}_{4}{ }^{+}-\mathrm{N}$ removal under different gas: water ratios.

The average concentrations of DO in A/O MBBRs under different gas: water ratios are shown in Figure 2. During the first continuous-flow operation mode and when the gas: water ratio equaled $5: 1$, the average $\mathrm{DO}$ concentrations in both aerobic MBBR and anoxic MBBR were $2.43 \mathrm{mg} / \mathrm{L}$ (standard deviation $(\mathrm{sd})=0.17 \mathrm{mg} / \mathrm{L}$ ) and $0.126 \mathrm{mg} / \mathrm{L}$ $(\mathrm{sd}=0.03 \mathrm{mg} / \mathrm{L})$, respectively. When the gas : water ratio increased to $7: 1$, the average DO concentrations in both $\mathrm{A} /$ O MBBRs increased by $62.96 \%(\mathrm{DO}=3.96 \mathrm{mg} / \mathrm{L}$, with

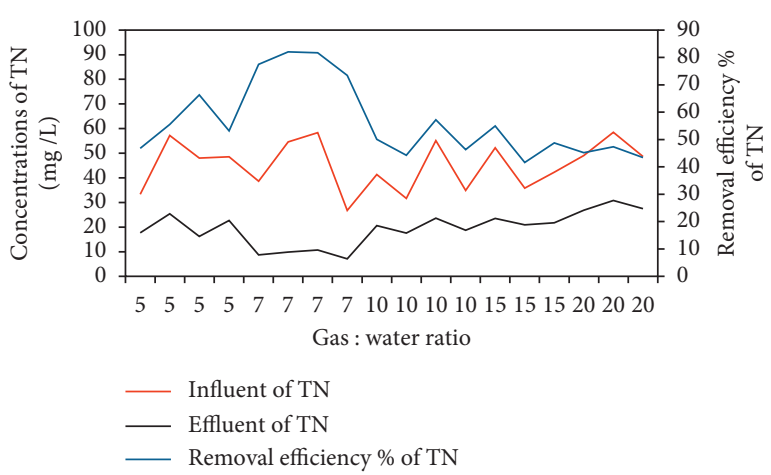

Figure 5: Performance of A/O MBBRs system for TN removal under different gas : water ratios.

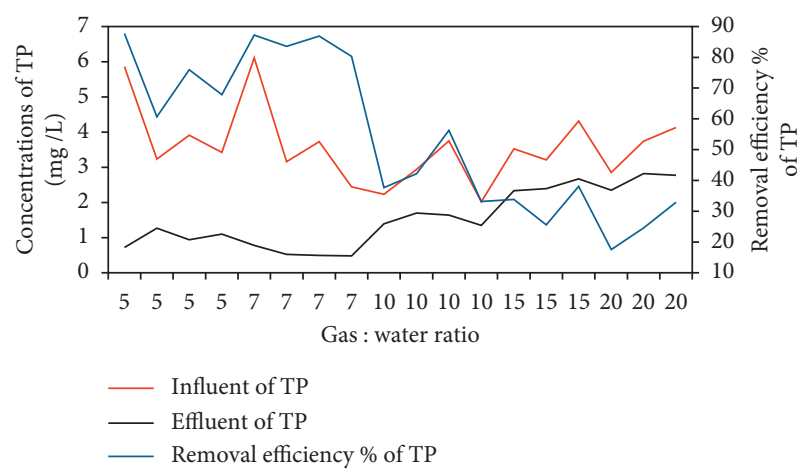

Figure 6: Performance of A/O MBBRs system for TP removal under different gas : water ratios.

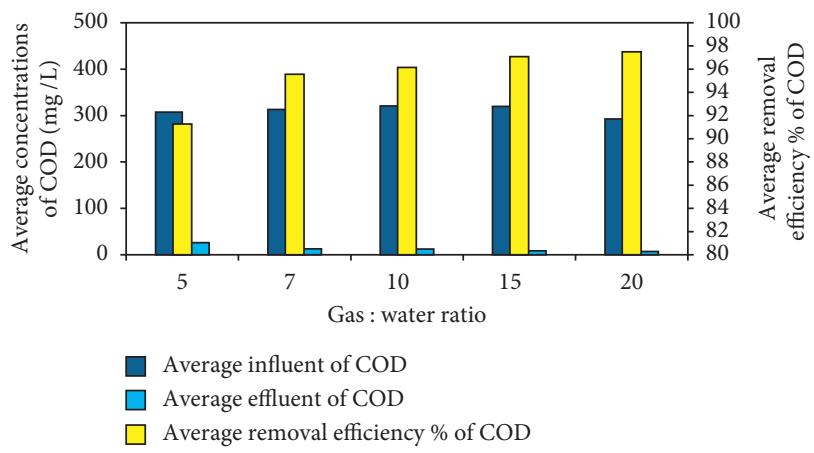

Figure 7: Effect of gas: water ratio on the average COD removal.

$\mathrm{sd}=0.11 \mathrm{mg} / \mathrm{L})$ and by $43.65 \% \quad(\mathrm{DO}=0.181 \mathrm{mg} / \mathrm{L}$, with $\mathrm{sd}=0.01 \mathrm{mg} / \mathrm{L}$ ), respectively. The continuous recycling of $\mathrm{NO}_{3}{ }^{-}$from the aerobic zone to the anoxic zone led to increase in the DO concentration in the anoxic MBBR, so the gas: water ratio increased, and the DO in anoxic MBBR increased until exceeding the permissible limit $(0.5 \mathrm{mg} / \mathrm{L})$ and reached $0.65 \mathrm{mg} / \mathrm{L}(\mathrm{sd}=0.08 \mathrm{mg} / \mathrm{L})$ when the gas : water ratio became $10: 1$. At gas: water ratio of $10: 1,15: 1$, and 20 : 1 , the A/O MBBRs treatment system became similar to the aerobic system with 2 aerobic MBBRs because DO in anoxic MBBR exceeded the permissible limit value, which is required to achieve the denitrification process, where the 


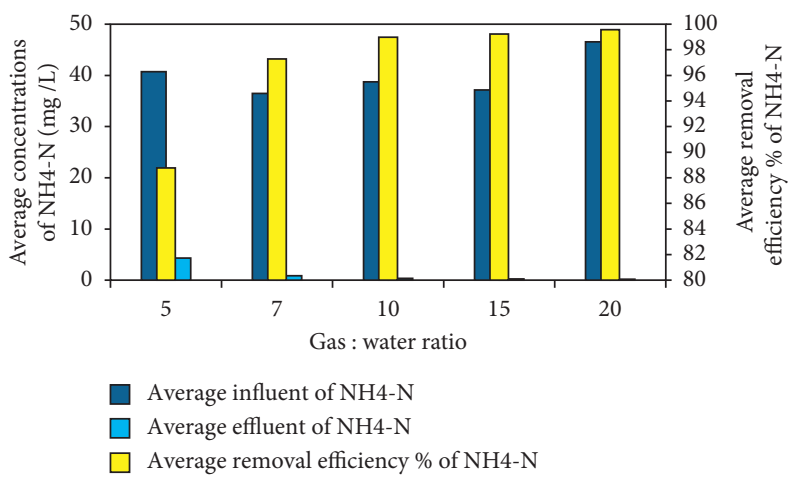

Figure 8: Effect of gas: water ratio on the average $\mathrm{NH}_{4}{ }^{+}-\mathrm{N}$ removal.

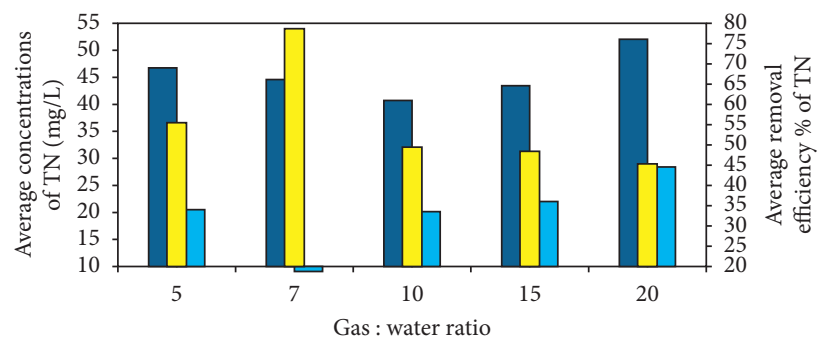

$\square$ Average influent of TN

$\square$ Average effluent of TN

$\square$ Average removal efficiency \% of TN

Figure 9: Effect of gas: water ratio on the average TN removal.

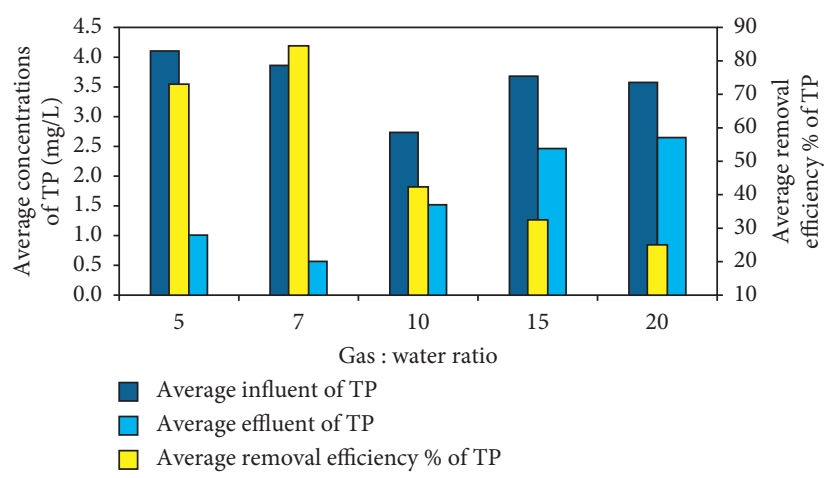

Figure 10: Effect of gas: water ratio on the average TP removal.

Gas : water ratio

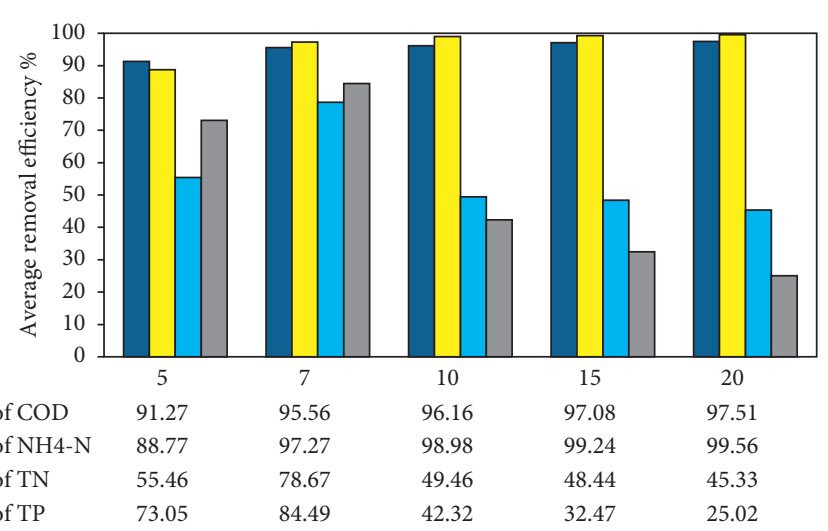

․ Average removal efficiency $\%$ of NH4-N

․ Average removal efficiency $\%$ of TN

73.05

84.49

42.32

32.47

FIgURE 11: Average performance of A/O MBBR system under different gas: water ratios. 
average concentration of $\mathrm{DO}$ in anoxic $\mathrm{MBBR}$ reached $0.94 \mathrm{mg} / \mathrm{L}(\mathrm{sd}=0.04 \mathrm{mg} / \mathrm{L})$ at gas : water ratio of $15: 1$, and $1.2 \mathrm{mg} / \mathrm{L}(\mathrm{sd}=0.16 \mathrm{mg} / \mathrm{L})$ at gas : water ratio of $20: 1$.

The results obtained from this study indicated that the A/ O MBBR treatment system with $50 \% \mathrm{~A} / \mathrm{O}$ volume ratio worked with high efficiency for removing both $\mathrm{NH}_{4}{ }^{+}-\mathrm{N}$ and $\mathrm{COD}$, and there was no significant effect of gas: water ratios on the efficiency of the system, where $\mathrm{R} \%$ of both $\mathrm{NH}_{4}{ }^{+}-\mathrm{N}$ and COD at different gas: water ratios $(5: 1,7: 1,10: 1,15: 1$, and $20: 1$ ) is in the range from $88.77 \%$ ( $\mathrm{sd}=4.94 \%)$ to $99.56 \%(\mathrm{sd}=0.24 \%)$, and from $91.27 \%(\mathrm{sd}=2.24 \%)$ to $97.51 \%$ ( $\mathrm{sd}=0.59 \%)$, respectively. At gas : water ratio of $5: 1$, the average effluent of $\mathrm{NH}_{4}{ }^{+}-\mathrm{N}$ and COD is $4.34 \mathrm{mg} / \mathrm{L}$ $(\mathrm{sd}=1.36 \mathrm{mg} / \mathrm{L})$ and $25.9 \mathrm{mg} / \mathrm{L}(\mathrm{sd}=3.49 \mathrm{mg} / \mathrm{L})$, respectively, while these concentrations become $<1 \mathrm{mg} / \mathrm{L}$ for $\mathrm{NH}_{4}{ }^{+}-\mathrm{N}$ and $<13 \mathrm{mg} / \mathrm{L}$ for COD when the gas: water ratio becomes in the range $7: 1-20: 1$.

The gas: water ratio significantly affects the performance of A/O MBR treatment system for removing of TN and TP. At gas : water ratio of $5: 1, \mathrm{R} \%$ of both TN and TP is $55.46 \%$ ( $\mathrm{sd}=8.11 \%)$ and $73.05 \%(\mathrm{sd}=11.6 \%)$, respectively, while the average effluent is $20.5 \mathrm{mg} / \mathrm{L}(\mathrm{sd}=4.3 \mathrm{mg} / \mathrm{L})$ and $1.01 \mathrm{mg} / \mathrm{L}$ $(\mathrm{sd}=0.23 \mathrm{mg} / \mathrm{L})$, respectively. As gas : water ratio increased to $7: 1, \mathrm{R} \%$ of both TN and TP increased by $41.85 \%(\mathrm{R} \%=$ $78.67 \%$ with $\mathrm{sd}=4.04 \%)$ and by $15.66 \%(\mathrm{R} \%=84.49 \%$ with $\mathrm{sd}=3.23 \%)$, respectively. At this value of gas : water ratio, the average effluent of TN becomes $<10 \mathrm{mg} / \mathrm{L}$, while that of TP becomes $<1 \mathrm{mg} / \mathrm{L}$; these values of average effluent concentration can meet many standards of wastewater treatment. When gas: water increased to $10: 1, \mathrm{R} \%$ of $\mathrm{TN}$ and $\mathrm{TP}$ dramatically decreased by $37.13 \%$ and $49.91 \%$, respectively, while the average effluent concentration increased to $20.15 \mathrm{mg} / \mathrm{L} \quad(\mathrm{sd}=2.62 \mathrm{mg} / \mathrm{L})$ for $\mathrm{TN}$ and to $1.52 \mathrm{mg} / \mathrm{L}$ $(\mathrm{sd}=0.18 \mathrm{mg} / \mathrm{L})$ for TP. At gas : water ratio of $15: 1-20: 1, \mathrm{R}$ $\%$ of $\mathrm{TN}$ and $\mathrm{TP}$ is in the range from $45.33 \%(\mathrm{sd}=1.97 \%)$ to $48.44 \%(\mathrm{sd}=6.68 \%)$, and from $25.02 \%(\mathrm{sd}=7.7 \%)$ to $32.47 \%(\mathrm{sd}=6.36 \%)$, respectively, while the average effluent of TN is $>22 \mathrm{mg} / \mathrm{L}$ and average effluent of TP is $>2.4 \mathrm{mg} / \mathrm{L}$. Finally, the system of A/O MBBRs with $50 \% \mathrm{~A} / \mathrm{O}$ volume ratio works efficiently for simultaneous nutrients and organic carbon removals only with gas: water ratio of $7: 1$.

\section{Conclusions}

According to the results obtained from this research, the following conclusions can be drawn:

(1) The concentration of $\mathrm{DO}$ in the aerobic reactor, $\mathrm{A} / \mathrm{O}$ volume ratio, and the internal $\mathrm{NO}_{3}{ }^{-}$recycling ratio have great effects on the DO concentration in the anoxic reactor and consequently on the denitrification rate

(2) The continuous recycling of $\mathrm{NO}_{3}{ }^{-}$from the aerobic zone to the anoxic zone leads to increase in the DO concentration in the anoxic MBBR, until exceeding the permissible limit $(0.5 \mathrm{mg} / \mathrm{L})$ and reaching $0.65 \mathrm{mg} / \mathrm{L}$ at gas : water ratio $10: 1$

(3) The A/O MBBR treatment system with $50 \% \mathrm{~A} / \mathrm{O}$ volume ratio and internal $\mathrm{NO}_{3}{ }^{-}$recycling ratio of
$100 \%$ works with high efficiency for removing both $\mathrm{NH}_{4}{ }^{+}-\mathrm{N}$ and COD, and there was no effect of gas : water ratios on the performance of the system

(4) The gas: water ratio significantly affects the performance of A/O MBR treatment system with $50 \% \mathrm{~A} / \mathrm{O}$ volume ratio and internal $\mathrm{NO}_{3}{ }^{-}$recycling ratio of $100 \%$ for removing $\mathrm{TN}$ and $\mathrm{TP}$

(5) The optimum gas: water ratio is $7: 1$, with the average removal efficiency of $\mathrm{TP}, \mathrm{TN}, \mathrm{NH}_{4}{ }^{+}-\mathrm{N}$, and COD being $84.49 \%, 78.67 \%, 97.27 \%$, and $95.56 \%$, respectively. Under this value of gas: water ratio, the average $\mathrm{DO}$ in both aerobic $\mathrm{MBBR}$ and anoxic $\mathrm{MBBR}$ is $3.96 \mathrm{mg} / \mathrm{L}$ and $0.181 \mathrm{mg} / \mathrm{L}$, respectively

(6) The A/O MBBR treatment system with $50 \% \mathrm{~A} / \mathrm{O}$ volume ratio, internal $\mathrm{NO}_{3}{ }^{-}$recycling ratio of $100 \%$, and gas: water ratio of $7: 1$ under full nitrificationdenitrification processes is very useful and sufficient technology for simultaneous nutrients and organic carbon removals

\section{Data Availability}

The data used to support the findings of this study are available from the corresponding author upon request.

\section{Conflicts of Interest}

The authors declare that they have no conflicts of interest.

\section{References}

[1] H. T. Y. Ibrahim, H. Qiang, W. S. Al-Rekabi, and Y. Qiqi, "Improvements in biofilm processes for wastewater treatment," Pakistan Journal of Nutrition, vol. 11, no. 8, pp. 708-734, 2012.

[2] H. T. Y. Ibrahim, Research on the performance of anoxic/ aerobic moving bed biofilm reactors for domestic wastewater treatment, Ph.D. thesis, Faculty of Urban Construction and Environmental Engineering, Chongqing University, Chongqing, China, 2014.

[3] H. T. Y. Ibrahim, Q. HE, and W. S. Al-Rekabi, "Effect of gas/ water ratio on the performance of combined cylindrical anoxic/aerobic moving bed biofilm reactors for biological nutrients removal from domestic wastewater by fully nitrification-denitrification processes," Research Journal of Applied Sciences, Engineering and Technology, vol. 7, no. 13, pp. 2655-2666, 2014.

[4] Y. Qiqi, H. Qiang, and H. T. Y. Ibrahim, "Review on moving bed biofilm processes," Pakistan Journal of Nutrition, vol. 11, no. 9, pp. 804-811, 2012.

[5] U. Welander, T. Henrysson, and T. Welander, "Nitrification of landfill leachate using suspended-carrier biofilm technology," Water Research, vol. 31, no. 9, pp. 2351-2355, 1997.

[6] B. Rusten, E. Mattsson, A. Broch-Due, and T. Westrum, "Treatment of pulp and paper industry wastewaters in novel moving bed biofilm reactors," Water Science and Technology, vol. 30, no. 3, pp. 161-171, 1994.

[7] B. Rusten, L. J. Hem, and H. Ødegaard, "Nitrification of municipal wastewater in moving-bed biofilm reactors," Water Environment Research, vol. 67, no. 1, pp. 75-86, 1995. 
[8] B. Rusten, L. J. Hem, and H. Ødegaard, "Nitrogen removal from dilute wastewater in cold climate using moving-bed biofilm reactors," Water Environment Research, vol. 67, no. 1, pp. 65-74, 1995.

[9] B. Rusten, O. Kolkinn, and H. Ødegaard, "Moving bed biofilm reactors and chemical precipitation for high efficiency treatment of wastewater from small communities," Water Science and Technology, vol. 35, no. 6, pp. 71-79, 1997.

[10] B. Rusten, C. H. Johnson, S. Devall, D. Davoren, and B. S. Cashion, "Biological pretreatment of a chemical plant wastewater in high-rate moving bed biofilm reactors," Water Science and Technology, vol. 39, no. 10-11, pp. 257-264, 1999.

[11] G. Andreottola, P. Foladori, M. Ragazzi, and F. Tatàno, "Experimental comparison between MBBR and activated sludge system for the treatment of municipal wastewater," Water Science and Technology, vol. 41, no. 4-5, pp. 375-382, 2000.

[12] G. Andreottola, P. Foladori, and M. Ragazzi, "Upgrading of a small wastewater treatment plant in a cold climate region using a moving bed biofilm reactor (MBBR) system," Water Science and Technology, vol. 41, no. 1, pp. 177-185, 2000.

[13] G. Andreottola, P. Foladori, G. Gatti, P. Nardelli, M. Pettena, and M. Ragazzi, "Upgrading of a small overloaded activated sludge plant using a MBBR system," Journal of Environmental Science and Health, Part A, vol. 38, no. 10, pp. 2317-2328, 2003.

[14] G. Andreottola, P. Foladori, M. Ragazzi, and R. Villa, "Dairy wastewater treatment in a moving bed biofilm reactor," Water Science and Technology, vol. 45, no. 12, pp. 321-328, 2002.

[15] B. Rusten, H. Ødegaard, and A. Lundar, "Treatment of dairy wastewater in a novel moving bed biofilm reactor," Water Science and Technology, vol. 26, no. 3-4, pp. 703-711, 1996.

[16] B. Rusten, J. G. Siljudalen, and H. Strand, "Upgrading of a biological-chemical treatment plant for cheese factory wastewater," Water Science and Technology, vol. 34, no. 11, pp. 41-49, 1996.

[17] S. J. Jahren, J. A. Rintala, and H. Ødegaard, “Aerobic moving bed biofilm reactor treating thermomechanical pulping whitewater under thermophilic conditions," Water Research, vol. 36, no. 4, pp. 1067-1075, 2002.

[18] B. Rusten, B. Eikebrokk, Y. Ulgenes, and E. Lygren, "Design and operations of the Kaldnes moving bed biofilm reactors," Aquacultural Engineering, vol. 34, no. 3, pp. 322-331, 2006.

[19] H. Ødegaard, B. Rusten, and J. Siljudalen, “The development of the moving bed biofilm process-from idea to commercial product," European Water Management, vol. 2, pp. 36-43, 1999.

[20] A. Anthonisen, L. Chun-jie, Y. Geng, Q. Zhou, and G. Gu, "Inhibition of nitrification by ammonia nitroasid," Journal of the Water Pollution Control, vol. 4, pp. 825-835, 1976.

[21] C. Helmer, S. Kunst, S. Juretschko, M. C. Schmid, K.-H. Schleifer, and M. Wagner, "Nitrogen loss in a nitrifying biofilm system," Water Science and Technology, vol. 39, no. 7, pp. 13-21, 1999.

[22] R. Canziani, V. Emondi, M. Garavaglia, F. Malpei, E. Pasinetti, and G. Buttiglieri, "Effect of oxygen concentration on biological nitrification and microbial kinetics in a cross-flow membrane bioreactor (MBR) and moving-bed biofilm reactor (MBBR) treating old landfill leachate," Journal of Membrane Science, vol. 286, no. 1-2, pp. 202-212, 2006.

[23] L. Falletti and L. Conte, "Upgrading of activated sludge wastewater treatment plants with hybrid moving-bed biofilm reactors," Industrial \& Engineering Chemistry Research, vol. 46, no. 21, pp. 6656-6660, 2007.
[24] L. Xiao, M. Rodgers, and J. Mulqueen, "Organic carbon and nitrogen removal from a strong wastewater using a denitrifying suspended growth reactor and a horizontal-flow biofilm reactor," Bioresource Technology, vol. 98, no. 4, pp. 739-744, 2007.

[25] E. Metcalf, Wastewater Engineering: Treatment and Reuse, McGraw-Hill, Boston, MA, USA, 4th edition, 2003.

[26] G. Pastorelli, R. Canziani, L. Pedrazzi, and A. Rozzi, "Phosphorus and nitrogen removal in moving-bed sequencing batch biofilm reactors," Water Science and Technology, vol. 40, no. 4-5, pp. 169-176, 1999.

[27] G. Tchobanoglous, F. L. Burton, and H. D. Stensel, Wastewater Engineering: Treatment and Reuse, McGraw-Hill, New York, NY, USA, 2003.

[28] R. Crites and G. Tchobanoglous, Small and Decentralized Wastewater Management Systems, McGraw-Hill, New York, NY, USA, 1998.

[29] J. Wang and N. Yang, "Partial nitrification under limited dissolved oxygen conditions," Process Biochemistry, vol. 39, pp. 1223-1229, 2004.

[30] G. Pastorelli, G. Andreottola, R. Canziani, C. Darriulat, E. de Fraja Frangipane, and A. Rozzi, "Organic carbon and nitrogen removal in moving-bed biofilm reactors," Water Science and Technology, vol. 35, no. 6, pp. 91-99, 1997a.

[31] L. J. Hem, "Nitrification in a moving bed biofilm reactor," Doctoral dissertation, Division of Hydraulic and Sanitary Engineering, The University of Trondheim, The Norwegian Institute of Technology, 1991.

[32] L. J. Hem, B. Rusten, and H. Ødegaard, "Nitrification in a moving bed biofilm reactor," Water Research, vol. 28, no. 6, pp. 1425-1433, 1994.

[33] N. Bernet, P. Dangcong, J.-P. Delgenès, and R. Moletta, "Nitrification at low oxygen concentration in biofilm reactor," Journal of Environmental Engineering, vol. 127, no. 3, pp. 266-271, 2001.

[34] A. E. F. Botrous, M. F. Dahab, and P. Mihaltz, "Nitrification of high-strength ammonium wastewater by a fluidized-bed reactor," Water Science and Technology, vol. 49, no. 5-6, pp. 65-71, 2004.

[35] G. Ciudad, O. Rubilar, P. Muñoz et al., "Partial nitrification of high ammonia concentration wastewater as a part of a shortcut biological nitrogen removal process," Process Biochemistry, vol. 40, no. 5, pp. 1715-1719, 2005.

[36] C. Fux, S. Velten, V. Carozzi, D. Solley, and J. Keller, "Efficient and stable nitritation and denitritation of ammonium-rich sludge dewatering liquor using an SBR with continuous loading," Water Research, vol. 40, no. 14, pp. 2765-2775, 2006.

[37] S. W. H. Van Hulle, H. J. P. Vandeweyer, B. D. Meesschaert, P. A. Vanrolleghem, P. Dejans, and A. Dumoulin, "Engineering aspects and practical application of autotrophic nitrogen removal from nitrogen rich streams," Chemical Engineering Journal, vol. 162, no. 1, pp. 1-20, 2010.

[38] APHA, AWWA, and WEF, Standard Methods for the Examination of Water and Wastewater, APHA, Washington, DC, USA, 21st edition, 2005.

[39] H. Helness, "Biological phosphorous removal in a moving bed biofilm reactor," Doctoral dissertation, Norwegian University of Science and Technology, Trondheim, Norway, 2007.

[40] U. Wiesmann, "Biological nitrogen removal from wastewater," in Advances in Biochemical Engineering/Biotechnology, A. Fiechter, Ed., Springer, Berlin, Germany, 1994.

[41] H.-D. Park and D. R. Noguera, "Evaluating the effect of dissolved oxygen on ammonia-oxidizing bacterial 
communities in activated sludge," Water Research, vol. 38, no. 14-15, pp. 3275-3286, 2004.

[42] W. G. Zumft, "Cell biology and molecular basis of denitrification," Microbiology and Molecular Biology Reviews: $M M B R$, vol. 61, no. 4, pp. 533-616, 1997.

[43] H. T. Y. Ibrahim, A. H. Al-Aboodi, and S. A. Abbas, "Nutrients removal from domestic wastewater in Basrah city (southern Iraq) using combined A2/O bio contact oxidation technology," E3S Web of Conferences, vol. 65, p. 05001, 2014.

[44] P. M. J. Janssen, K. Meinema, and H. F. van der Roest, Biological Phosphorus Removal: Manual for Design and Operation, IWA Publishing, Amersfoort, Netherlands, 1st edition, 2002.

[45] T. Saito, D. Brdjanovic, and M. C. M. Van Loosdrecht, "Effect of nitrite on phosphate uptake by phosphate accumulating organisms," Water Research, vol. 38, no. 17, pp. 3760-3768, 2004.

[46] E. Broda, "Two kinds of lithotrophs missing in nature," Zeitschrift fur Allgemeine Mikrobiologie, vol. 17, pp. 491-493, 1997.

[47] M. S. M. Jetten, M. Strous, T. van de Pas-Schoonen et al., "The anaerobic oxidation of ammonium," FEMS Microbiology Reviews, vol. 22, pp. 421-437, 1999. 